\title{
Rechtsgeschichte
}

www.rg.mpg.de

http://www.rg-rechtsgeschichte.de/rg10

Zitiervorschlag: Rechtsgeschichte Rg 10 (2007)

$\operatorname{Rg} 1 \mathbf{0}_{2007}$

$152-168$

http://dx.doi.org/10.12946/rg10/152-168

\section{Toomas Kotkas}

\section{Pardoning in Nineteenth-Century Finland}

At the Interface of Early Modern and Modern Criminal Law 


\section{Abstract}

During the last few years many new studies on the history of pardoning in the early modern period have questioned the old conception of pardoning merely as an expression of a ruler's mercy. Now, the system of pardoning is seen rather as an institutional framework for the condemned and the authorities to negotiate for the punishment. However, the 19 th century pardoning systems and practices still seem to be a reasonably uncovered area. This article shows that the pardoning practice of 19th century Finland still embodied features of early modern criminal law. Pardoning was used to take into account mitigating circumstances, the social capital of the petitioners was important for the outcome, and the procedure involved symbolism. On the other hand, modern features also appeared. Local community had lost its influence on the procedure, pardoning power was to a large extent delegated to the judicial authorities with clear guidelines, and fiscal interests were no longer involved in the pardoning system. The article also shows that the reforms carried out in the Finnish criminal law during the 19th century had a clear impact on the pardoning practice. Pardoning began to lose its significance. However, the pardoning system did not simply give way to the standards of modern criminal law. On the contrary, it functioned as an important transitional tool for modernizing the material criminal law. 


\section{Pardoning in Nineteenth-Century Finland}

At the Interface of Early Modern and Modern Criminal Law

I. Pardoning in the History of Criminal Law

During the last few years a number of new studies has been published on the history of petitioning in the early modern period. ${ }^{\mathrm{I}}$ Many of these studies have "widened the conceptions of the early modern period that has so far usually been characterized with such terms as stightening of control`, state formation`, reason of State`, ssocial disciplinization ‘, 'police and rabsolutism $«{ }^{2}{ }^{2}$ It has been shown that the political and juridical intercourse between the authorities and people did not exclusively follow the »order/ obedience « logic of laws and decrees. Instead, the system of petitioning, too, formed an important means of communication between the ruler and his subjects in the early modern period. Various types of petitions and letters - official and unofficial - were widely used in politics, administration and justice systems of the early modern societies. ${ }^{3}$

Owing to the increased interest in petitioning in general, new light has also been shed on the functions of petitioning within the criminal justice system - i.e. petitions for pardon - of the early modern period. It was long common within the research on the history of criminality to portray pardons - quite one-sidedly - as expressions of a ruler's mercy or merely as a means of renouncing the lawful punishment. ${ }^{4}$ However, recent studies have questioned the legitimacy of this view and put forward new interpretations that have emphasized the functional aspects of the pardoning system in the early modern period. In many of these studies, the system of pardoning is now seen rather as an institutional framework for the defendant/condemned and the authorities to negotiate (aushandeln) for the punishment. ${ }^{5}$ The important role that the pardoning system obtained in the early modern criminal justice system can be seen as a kind of substitution for the loss of orality and immediacy when the accusatorial criminal process was replaced by the inquisitorial system. ${ }^{6}$

der Vormoderne, Konstanz 2000, 478-480; M. Dinges, Justiznutzungen als soziale Kontrolle in der Frühen Neuzeit, in: A. BlauerT, G. SCHWERHOFF (eds.), Kriminalitätsgeschichte, 535 ; HÄRTER, Das Aushandeln (nt. 4); K. HërTER, Policey und Strafjustiz in Kurmainz. Gesetzgebung, Normdurchsetzung und Sozialkontrolle im frühneuzeitlichen Territorialstaat, Frankfurt a. M. 2005, 495-
5I 5 ; H. RudOLPH, "Sich der höchsten Gnade würdig zu machen «. Das frühneuzeitliche Supplikenwesen als Instrument symbolischer Interaktion zwischen Untertanen und Obrigkeit, in: C. Nubola, A. Würgler (eds.), Bittschriften (nt. I).

6 HÄrTER, Strafverfahren (nt. 5) 478-480; Härter, Das Aushandeln (nt. 4) 247-248; HärTER, Policey (nt. 5) 497-498.

\author{
5 K. HÄrter, Strafverfahren im \\ Inquisition, Entscheidungsfin- \\ dung, Supplikation, in: A. BLAU- \\ Kriminalitatsgeschichte. Beiträge
}


Although our knowledge on pardoning in the early modern period has substantially improved, the I9th-century pardoning systems and practices still seem to be a reasonably uncovered area. A recent review article on the criminal law history of the I9th century claims that "[o]nly one study scrutinizes more closely what kind of factors and forces were determinant when deciding on a petition for pardon . $^{7}$

The aim of this article is thus to shed some new light on the pardoning practices in the I9th century. The article is based on my study of pardoning in criminal and vagrancy cases in I 9 th-century Finland. ${ }^{8}$ The period in question is particularly interesting because the Finnish criminal law was modernized during the course of the century. In the study, I put forward two questions: I. What was the logic of pardoning? In other words, was it somehow regulated, how consistent was it, were there any signs of arbitrariness, and which factors influenced the decision making? 2. How did the criminal law reforms that were carried out during the latter half of the century affect the pardoning system? In order to answer these research questions, empirical data from I,254 pardon petitions and decisions from the years I82I, I84I, I86I, I88I, and I90I was collected. ${ }^{9}$ As the title of my article implies, the study revealed that the I9th-century pardoning system in Finland still embodied many features that could be said to have been characteristic of the early modern pardoning system. However, these features weakened towards the end of the century due to the reforms of criminal law. But before going to the conclusions of this article in any more detail, I shall next introduce the empirical findings of my study.

\section{Pardoning in Nineteenth-Century Finland - Empirical Findings}

Finland became an autonomous grand duchy of the Russian empire in 1809 and remained so until it gained independence in I9I7. In the annexation, Finland was able to maintain its (Swedish) laws, including the Constitution of $\mathbf{1 7 7 2}$. This constitution was enacted during the absolute reign of Gustav III (I77I-I792) and it thus invested extensive powers to the ruler. Among these powers was, of course, the prerogative of pardon. The constitution be-

\footnotetext{
7 R. Habermas, Von Anselm von Feuerbach zu Jack the Ripper. Recht und Kriminalität im I9. Jahrhundert. Ein Literaturbericht, in: $\operatorname{Rg}_{3}$ (2003) I 5O-I 5 I. The article is referring to Petra Overath's study on death sentences and pardons in I9th-century Bavaria, P. Overath, Tod und Gnade. Die Todesstrafe in Bayern im I9. Jahrhundert, Köln, Weimar, Wien 200I.
}

8 T. KotKas, "Suosiosta ja armosta «. Tutkimus armahdusoikeuden historiasta autonomian ajan Suomessa [By Grace and Mercy. A Study on the History of Right of Pardon in Nineteenth-Century Finland], Helsinki 2003.

9 My study is based on the records, acts and proceedings of the Archives of the Judicial Department of the Senate (SOO) which are kept in the (Finnish) National Ar- chives. The number of the pardon petitions of each sample year was 60 (I 82I), 384 (I 84I), 303 (I86I), 296 (I88I), and 2II (I90I). 
stowed on the ruler an exclusive right to grant pardon. ${ }^{10}$ This right was further confirmed in the Regulation given by Alexander I in order to organize the Cabinet Council (i.e. the Senate ${ }^{\mathrm{II}}$ ) from I 809. The regulation also ordered that all the petitions for pardon were first to be sent to the Judicial Department of the Council (i.e. the Supreme Court), which was to attach its opinion to the petitions and send them on to the ruler. However, the ruler was not bound by the opinion of the Judicial Department. ${ }^{\mathrm{I} 2}$

Also the criminal law of the old mother country remained valid in the new grand duchy of Finland. As a result, the penal statutes of the Swedish Code of $\mathrm{I} 734$ formed the basis for criminal legislation. These statutes reflected the conceptions of I7th-century criminal law and were, therefore, highly outdated. However, the Finnish penal legislation as a whole was not reformed until the end of I 9 th century, when the Penal Code of 1889 came into force in $\mathrm{I} 894 .{ }^{\mathrm{I}} \mathrm{T}$ This Code of $\mathrm{I} 889$ abolished pillory, corporal punishments and the death penalty (except for high treason), introduced penal scales and imposed imprisonment as the main form of punishment. Some important partial reforms had already been carried out earlier during the century. In I 826, Alexander I issued a decree in which he announced that, with the exception of high treason, he would grant pardon to all who had been or would be sentenced to death and commute their capital punishments to fixed-term or life-long hard labour, corporal punishment and public penance. ${ }^{\mathrm{I}}$ As a consequence, the year I 825 was the last year in which a death penalty was ever enforced in peacetime Finland. Furthermore, in I866 the Diet enacted two statutes which abolished capital punishment and introduced penal scales concerning involuntary manslaughter and infanticide. ${ }^{{ }^{5}}$ So, this was the condition and development of the criminal legislation during the I9th century. Let us now turn to the petitions for pardon. ${ }^{16}$

\section{The Year I 82I - Low Total Number of Petitions}

During the first sample year (I82I), the Emperor received a total of 60 petitions for pardon. Among the petitioners were people convicted of various crimes: manslaughter, infanticide, larceny, smuggling, etc. A little more than half (3I) of the petitioners were, however, vagrants who had been sentenced to public labour. The

Io Kongl. Maj:ts och Rikens Ständers faststäldte Regerings-Form (2I August 1772), 9 \$.

II The Council was renamed in I8I 6 as the Senate.

I2 Hans Keiserl. Maj:ts Nådiga Reglemente för Dess tillförordnade Regerings-Conseil i Storfurstendömet Finland (6/1 8 August I 809), paragraphs $34-37$.

옹

I3 Rikoslaki (I9 December I 889).

I4 Keisarillisen Majestätin Armollinen Julistus, Kuolemaan tuomittuin, waan Suosiosta ja Armosta hengen rangaistuksesta pelastettuin pahantekijäin lähettämisestä yhteiseen työhön Siperian kaukembana olewaisiin Gouvernementiin (2I April I826).

I 5 Asetus lapsenmurhasta sekä sikiön ulosajamisesta ja ulospanemisesta, kuin myöskin muutamilta sala- wuoteuden tapauksilta (26 October I 866); Asetus taposta, ilman kuolettamisen aikomusta, ja muusta rääkkäyksestä ihmistä kohtaa (26 October I 866). I 6 The sample years - I $82 \mathrm{I}, \mathrm{I} 84 \mathrm{I}$, I 86I, I $88 \mathrm{I}$ and I90I - were chosen so as to be able to analyze the exercise of pardon before and after each criminal law reform. 
relatively large number of vagrant petitioners can be explained by the fact that if a person could not provide himself »legal guardianship «, i.e. employment, he was condemned for vagrancy and sentenced to public labour by the governor. The normal sentence was six months or as long as it took for the vagrant to find himself a job. However, acquiring legal guardianship often proved to be very difficult, especially during the first half of the I9th century, owing to the rapid growth in population, which in turn produced an oversupply in the labour force. So, the alternative way of being released from a workhouse or a correctional institution was that the person was granted a pardon.

Of all the petitions in I $82 \mathrm{I}$ ten were approved. Among these, six people had been sentenced to the death penalty for manslaughter or infanticide, and one for forgery. Their sentences were commuted to fixed-term or life-long hard labour, corporal punishment and public penance. These decisions were justified by citing "mitigating circumstances " - i.e. the crime was committed either in anger, in self-defence or in a weak state of mind. In addition to the six capital cases, one person who had been found guilty of smuggling received pardon because the statute on the grounds of which he was convicted had not yet been publicly announced in his home parish at the time of the act. Two vagrants were pardoned because they had served their sentences for a longer period of time and their conduct had been blameless. The reason for the rejections was normally only briefly stated, "No grounds for an approval $\ll \cdot{ }^{17}$

The Year I84I - Vagrants as the Majority

of the Increased Number of Petitioners

Compared to I82I, the number of pardon petitions in I84I was substantially higher. A total of 384 petitions of pardon were submitted to the Emperor during that year. The increase can be explained, at least partly, by the rapid growth of the Finnish population during the first half of the I9th century. ${ }^{18}$ The population growth was fastest among the people without landed property, which resulted, among other things, in the increase of crime and vagrancy. In addition, the Finnish workhouse system was in poor condition. In fact, there were not really separate workhouses for vagrants. Vagabonds had to serve their public labour sentences at

I7 KotKas, "Suosiosta « (nt. 8) I38-

I49.

I 8 During the first 50 years of the

I 9 th century, Finland's population

doubled from 832,700 to

I,637,000 inhabitants. 
I9 V. Virtanen, Työ- ja ojennuslaitokset irtolaislainsäädännön ja vankeinhoitotoimen kehityksen valossa ı 8०o-luvun puolivälissä [The Mid-Nineteenth Century Work and Correctional Institutions in the Light of Vagrancy Legislation and Prison Administration], Helsinki I943, 76-I4I.

20 The rest $\left({ }_{1} 8_{3}\right)$ of the petitioners were convicted of various types of crimes - among them 50 people for homicide/manslaughter and 42 people for different types of larceny. KotKas, »Suosiosta « (nt. 8) I 57-I 59.

2 I Keisarillisen Majestäätin Armollinen Asetus ja Julistus Siitä, mitä niiden Hänen Keisarillisen Majestäätin eteen alamaisuudessa tygölähetettäwiin anomuxiin suhteen, niinkuin myös rangaistuxiin ja edeswastauxiin huojennuxeen, [Leuteraatio] ja moniaissa asioissa wapauttamiseen [Dispense] suhteen, tästälähin tulee waarinotettawaxi (2 June I826), $3 \mathbb{S}$.

22 As a further indication of this, the secretary of the Judicial Department of the Senate had underlined all the passages in the documents that referred to previous convictions or workhouse sentences.

23 One petitioner was pardoned because of a false interpretation of the law in sentencing; two petitioners received commuted sentences of their corporal punishment to imprisonment on bread and water for medical reasons; one petitioner was pardoned from the pillory because of the out-datedness of the punishment; two petitioners were pardoned on the grounds of an amnesty; and, finally, two petitioners were pardoned because the misdeed had been done out of thoughtlessness, rather than ill will. KoTKAS, "Suosiosta « (nt. 8) I 50-I7I.

24 If the delinquent petitioner had been sentenced to life imprisonment, the requirement was that he had served his sentence a minimum of four years. If the original sentence was five years or more, the time-requirement was two years. For the shorter sentences, the requirement was a minimum of one year. However, no time

the old fortresses usually together with criminals. These institutions were heavily overcrowded. ${ }^{19}$ It is then no surprise that of all the petitioners of pardon in $\mathrm{I} 84 \mathrm{I}$, no fewer than $20 \mathrm{I}$ were convicted of vagrancy. ${ }^{20}$

A total of 74 petitioners were pardoned in $\mathrm{I} 84 \mathrm{I}$. Among them were 59 vagrant petitioners. The authority to pardon vagrants had been delegated to the Justice Department of the Senate already in I 826 by a decree. ${ }^{2 \mathrm{I}}$ The explicit grounds for their pardons were that the petitioner "had served his sentence a longer period of time and his conduct had been blameless «. By contrast, the rejections were again grounded simply: »no grounds for approval «. If one compares the served time and conduct of those vagrant petitioners who were pardoned to the corresponding of those who were not, there seems to be very little difference. However, a quantitative analysis indicated that most vital for the outcome was the length of the petitioner's vagrant/criminal record..$^{22}$ If a petitioner had a vagrant or criminal background, he had to serve a longer time in the workhouse than the first-timers. In addition to the 59 pardoned vagrants, the Emperor pardoned six people who were sentenced to the death penalty. Their pardons were consistent with the Imperial Decree of 1826 in which Nikolai I had made a declaration to commute all the future death penalties to life-long hard labour, corporal punishment and public penance. Finally, nine other delinquents were pardoned. ${ }^{23}$

\section{The Year I86I - A Majority of the Petitioners were pardoned to Siberia as Settlers}

In the next sample year, I86I, the number of petitioners was 303. Compared to the situation in I $84 \mathrm{I}$, the Emperor had passed two new important statutes concerning pardoning. In a resolution from I 856, Alexander II decided to assent to all the petitions of delinquents and vagrants who wanted to be sent as settlers to the colonies of Siberia, if certain prerequisites were met. ${ }^{24}$ In fact, this had already been the practice from 1848 onwards. ${ }^{25}$ The second significant statute was the decree from I 859 , by which the Emperor delegated the right to pardon petitioners, who asked that their corporal punishment (flogging or whipping) be commuted to imprisonment on bread and water for medical reasons, to the Justice Department of the Senate. ${ }^{26}$

ded that all the deportees were of proper age, health and character. See A. Juntunen, Suomalaisten karkottaminen Siperiaan autonomianaikana ja karkotetut Siperiassa [The Deportation of Finns to Siberia in the Nineteenth Century and the Deportees in Siberia], Helsinki I983, 42-44.

25 Deportations had been used in the Russian empire since the I 6 th century. At the beginning of the I9th century, this practice was rationalized in order to strengthen the resettlement of Siberia. In Finland, the deportations came to be seen as a respectable alternative, due to the unsatisfactory state of the local prison system. Finally, from I 848 onwards, on account of the Finnish initiative, the Emperor began de facto to pardon Finnish convicts who had petitioned to be sent as settlers to the 
In I86I, more than half $(\mathrm{I} 6 \mathrm{I} / 303)$ of the petitioners were pardoned. The largest group among those pardoned was 74 vagrant petitioners whose public labour sentence was commuted to a "fresh start " as settlers in the colonies of Siberia. In addition to these vagrants, 36 delinquents were pardoned to be sent to Siberia as settlers. Furthermore, I7 people who had been sentenced to death were pardoned in accordance with the 1826 decree; in I 6 cases, the Justice Department of the Senate used its power to commute corporal punishment to imprisonment on bread and water for medical reasons on the grounds of the I 859 decree; and finally, 18 other petitioners were pardoned. ${ }^{27}$

\section{The Year I 88 I - Numerous Corporal Punishments Commuted to Hardened Imprisonment}

In I 88 I, a total of 296 people petitioned for pardon. Among them were no longer persons who had been sentenced to death due to the reform of $\mathrm{I} 866$, by which capital punishment for involuntary manslaughter and infanticide was abolished. Furthermore, there were only 18 vagrant petitioners. This was due to the reforms in the vagrant legislation. In I 865 , the legal prerequisites of vagrancy were tightened by a new decree. A person did not qualify as a vagrant solely on the grounds of being unemployed. Now, it was additionally required that he had led an idle and indecent life. Furthermore, sentencing someone to a workhouse was to be used only if issuing a warning or an order to acquire a job did not have the desired results. Also the scope of the governors' right to release vagrants from workhouses and correctional institutions was extended. ${ }^{28}$

A total of Ioo petitioners received pardon in I 88 I. In 77 of the cases, the Justice Department of the Senate used its power to commute corporal punishment to imprisonment on bread and water based on the grounds of the 1859 decree. By contrast with the situation in $\mathrm{I} 86 \mathrm{I}$, medical certificates were no longer necessary in $\mathrm{I} 88 \mathrm{I}$. These petitioners were mostly $(73)$ convicted of repeated larceny of which the law still provided corporal punishment. An additional I 6 petitioners were pardoned, and their punishments commuted to deportation to the colonies of Siberia. Furthermore, five petitioners were pardoned from pillory because of the outdatedness of their punishments; one was pardoned because the

colonies in Siberia for life. The system of deporting Finnish convicts to Siberia was renounced in I 887 . See JunTunEN, Suomalaisten (nt. 24).

26 Keisarillisen majesteetin Armollinen Asetus lisäyksistä siihen, mitä tätä ennen [2 June I 826] on säännetty asiain käyttämisestä Keisarillisessa Suomen Senaatissa (28 November I 859).
27 Two petitioners were pardoned due to the long period they had already spent in prison; four petitioners had their public penance commuted to a private one; two petitioners were pardoned for medical reasons to life-long imprisonment in Finland instead of hard labour in Siberia; four petitioners were pardoned because their misdeeds had been done out of thoughtlessness, rather than ill will; two petitioners were granted pardon in order to safely return to their home country to get their cases duly investigated; one petitioner was allowed to serve his sentence in a local prison; two were fully pardoned for medical reasons; finally, one vagrant petitioner was pardoned so that he could acquire employment. See KotKas, "Suosiosta « (nt. 8) I72I 85 .

28 K. J. StÅHlberg, Irtolaisuus Suomen lain mukaan [Vagrancy According to the Finnish Law], Helsinki I 893, 36-4I. 
misdeed had been done out of thoughtlessness rather than ill will; and one received pardon for serving her sentence for a longer period of time (I I years). ${ }^{29}$

\section{The Year I90I - Pardoning as a Part of} the Newly Established Parole System

During the last sample year, I90I, a total of 2 I I petitions were submitted. The year I90I differed substantially from the earlier sample years due to the new Criminal Code of 1889 which had abolished pillory, corporal punishments and capital punishment (with the exception of regicide and high treason), and introduced penal scales. Thus, there was no longer a need to use the prerogative of pardon to mitigate the harshness of the old and outdated criminal law. However, the right of pardon assumed a new function. The new Decree on the Enforcement of Punishment of I 889 introduced a parole system in Finland. ${ }^{30}$ If the prerequisites were met, the board of the particular prison, with the consent of the prisoner in question, was to draw a petition for the prisoner's release on parole. ${ }^{3 \mathrm{I}}$ The prison board was to send the petition to the National Prison Board in order to get its opinion. The National Prison Board then sent the petition on to the Judicial Department of the Senate. Even though the Judicial Department of the Senate was invested with the power of decision, the petition still had to be addressed to the Emperor. The majority (I74/2 I I) of all the pardon petitions submitted in I90I were petitions for parole.

A total of 167 petitioners were pardoned in I901. A majority of these ( 156 ) were pardoned on parole. They all had served their sentence for the required time and had behaved blamelessly. Ten other petitioners were pardoned because their sentencing had been based on a false interpretation of the law. Furthermore, one petitioner received pardon on the grounds of his old age and poor physical health. ${ }^{32}$

3. The Logic of Pardoning: Early Modern Negotiating ...

The empirical findings of my study indicate that pardoning in I9th-century Finland still embodied several features that were characteristic of the early modern system of pardoning and crim-

29 KotKas, "Suosiosta « (nt. 8) 202$2 \mathrm{I} 3$.

30 K. Maj:n armollinen Asetus rangaistusten täytäntöönpanosta ( 19 December I 889).

3 I The conditions were that the convict's conduct had been blameless, his livelihood outside the prison was secured, and that he had served three-fourths of his sentence. The time requirement for the prisoners for life was I 2 years.
32 Kotkas, "Suosiosta « (nt. 8) 220232. 
inal law in general. Firstly, there were several petitioners who had been sentenced to death for manslaughter or infanticide but who pleaded to mitigating circumstances. For instance, as the data from I 82 I showed, the death penalty of six such petitioners was commuted to fixed-term or life-long hard labour, corporal punishment and public penance on the grounds of mitigating circumstances, i.e. the crime was committed either in anger, in self-defence or in a weak state of mind. And even after abolishing the death penalty by the 1826 Imperial Decree, which made pardon in these cases automatic, the doctrine of mitigating circumstances still continued to play a role in the pardoning practice. If the plea to mitigating circumstances was found justifiable, the death penalty was commuted to fixed-term or life-long hard labour at the domestic fortresses instead of the factories or mines of Siberia.

The practice of commuting death sentences in manslaughter cases because of mitigating circumstances was a centuries-old tradition in Europe. Ever since the late Middle Ages, and throughout the early modern period, the pardoning system was used for this purpose. In France, for instance, the lettres de rémission were frequently used, particularly in cases of involuntary manslaughter, in order to commute death sentences to more lenient punishments. By the I6th century, this right had become a prerogative of the ruler. Courts did not have the authority to mitigate sentences in capital cases. The practice was not abolished until the French Revolution. ${ }^{33}$ Early modern jurisprudence had also paid attention to the ruler's right of pardon. For instance, during the period of ca. I650-I800, a concept of ius aggratiandi was developed in the German jurisprudential literature. By and large the concept referred to the royal prerogative of pardon. Conditions for the exercise of pardon - concerning also the cases of involuntary manslaughter - were developed in numerous dissertations; i.e. when pardon was permissible and when not. ${ }^{34}$

It would be misleading, however, to claim that only legal aspects, i.e. the doctrine of mitigating circumstances, were pivotal when deciding on the petitions of those delinquents who had been convicted for involuntary manslaughter and infanticide. It has been argued that legal arguments played, in fact, only a lesser role in the decision-making policies of the pardoning authorities in the early modern German states because the mitigating circumstances had already been taken into consideration by the courts - at least in

33 J. Foviaux, La Rémission des Peines et des Condamnations. Droit monarchique et droit moderne, Paris I970, 3I-34, 5I-54, 77; N.Z. DAvis, Fiction in the Archives. Pardon Tales and Their Tellers in Sixteenth-Century France, Cambridge I987, 36-76; J.-M. CARbasse, Introduction historique au droit penal, Paris I990, I 27-I 28; C. GAUvARD, La justice pénale du roi de France à la fin du
Moyen Age, in: X. Rousseaux, R. LEvy (eds.), Le pénal dans tous ses etats. Justice, Etats et Sociétés en Europe (XIIe-XXe siècles), Bruxelles I997, 99-I05; B. GARNOT, Justice et société en France aux XVIe, XVIIe et XVIIIe siècles, Paris 2000, I74-I77. Concerning the Netherlands, see H. DE SCHEPPER, Privileg und Gratia in den Burgundisch-Habsburgischen Niederlanden, I400-I62I. Eine historisch-theoretische Betrachtung, in: Das Privileg im europäischen Vergleich 2, hg. von B. Dölemeyer und H. MohnHAUPT, Frankfurt a. M. I999, 242-243.

34 T. BRÜCKNER, Das `Ius Aggratiandi<: Gnade und Recht und ihre Interaktion in der Rechtswissenschaftlichen Literatur der frühen Neuzeit, in: Tijdschrift voor Rechtsgeschiedenis 69 (200I) 57-79. 
theory. It has been suggested that the decisions in pardon matters were rather done in the context of "gute Policey«. That is, the question was largely about maintaining public safety and good order. For instance, the petition of a local, hardworking father of a family was more likely to be approved than that of a wandering stranger. ${ }^{35}$ It seems that the situation was the same in France. Unwanted and suspicious elements of the society (recidivists, brigands, rebels, foreign vagabonds, etc.) were most likely to be deprived of pardon. They eventually served their death penalties, or were otherwise excluded from the society - for instance, by means of banishment. ${ }^{36}$

So, the Finnish practice of making a distinction between those petitioners who had committed their crime under mitigating circumstances and those who had not - even after the Decree of I 826 - can also be understood in this broader context of gute Policey. The absence of mitigating circumstances meant that the petitioner was more serious a threat to the society and had to be thus deported to Siberian factories or mines for life. In fact, the I 826 Decree spoke of »common order " as a ground for this distinction. ${ }^{37}$ Furthermore, when the then Procurator General, Matthias Calonius, was asked beforehand of his opinion whether the approval of the Diet would be needed for the introduction of the deportations, his answer was negative. He saw it merely as a »useful police business «. ${ }^{3}$

The aspect of public safety and good order was more obvious in the case of vagabond petitioners who formed a significant proportion (ca. $27 \%$ ) of all the petitioners in the empirical data of my study. As already mentioned above, due to the increase of loose population and the poor condition of the Finnish workhouse system the few existing penal institutions became rapidly overcrowded during the first half of the I 9 th century. There simply were not enough places for all the convicted criminals and vagrants. The authorities were thus more or less forced to consent at least to some of the petitions. The Judicial Department of the Senate was more inclined to pardon vagrants (rather than criminals) to release the pressure in the age-old and over-burdened correctional institutions. And as the data from I $84 \mathrm{I}$ showed, essential for the decision making seems to have been the vagabond/criminal history of the vagrant petitioner. If the petitioner had no prior record, he had a better chance of receiving a pardon than those vagrants who had

35 HÄrter, Strafverfahren (nt. 5) 478-480; HärTER, Das Aushandeln (nt. 4) 265-269; HÄRTER, Policey (nt. 5) 5II-5I 2.

36 B. Garnot, Justice (nt. 33) I79I $8 \mathrm{I}$.

37 Keisarillisen (nt. I4).

38 Juntunen, Suomalaisten (nt. 24) 29-3I. 
been previously found guilty of vagabondage or crime. The authorities were thus evaluating the threat that each individual petitioner might pose for the public order. The Finnish experience resembles the situation in I 8th-century Kurmainz. In Kurmainz »the load of the penal institution [Zuchthaus] also played a role: If it was overcrowded and the more >dangerous< delinquents needed to be imprisoned, the government was more ready to approve a petition for remission from a local petitioner « ${ }^{39}$

After I 848, when the deportations were also extended to vagrants, the vagabond/criminal record of the petitioner seems to have become irrelevant in the Finnish decision-making process. Vagrants were pardoned to Siberia irrespective their vagabond/ criminal history. Now, it was only required that the petitioner was of proper age and in good physical health in order to endure the strains of the deportation. Nevertheless, the aspect of public order was still very much of importance. Vagrants were deported to Siberia as settlers in order to keep possible troublemakers away from the home country.

The relatively high number of vagabond petitioners bears telling witness to the structure of the system of social control in the early modern period. The system consisted not only of criminal law which was meant to repress the more serious forms of deviant behaviour, i.e. felonies (peinliche Gerichtsbarkeit), but also of »inferior " systems of social control such as police regulations (Policeynormen). As it has been recently emphasized, the understanding of the early modern control system is not possible without taking into consideration the aspect of Policey. The leitmotif of the early modern states was the maintenance of good societal order. ${ }^{40}$

This is also the place where the elements of negotiation came into play in the I 9 th-century Finnish pardoning system - at least to a certain extent. It has recently been claimed in several studies on pardoning in the early modern period that what was at stake in the pardoning process was often the reputation or the "social capital « of the petitioner. If the petitioner could convince the authorities that he was in some way valuable to his family or to the community, chances for pardon were significantly higher. In practice, this could mean that the petitioner was the sole supporter of the family. It was thus common that the family and/or the members of the local community wrote petitions for the accused/condemned. This way, the local community - both rural and urban - vouched for the 
petitioner's good character. ${ }^{4 \mathrm{I}}$ In the Finnish I9th-century experience, elements of negotiation appeared in the fact that the sentence that was pronounced in court was not necessarily the final one, as the manslaughter and infanticide cases with mitigating circumstances indicated. Similarly, the workhouse sentence that vagrants received upon order of the governor did not necessarily hold if the vagrant petitioner had no prior convictions. In this sense, and especially in respect to vagrant petitioners, the petitioner could use his blameless reputation as an asset in trying to negotiate a better outcome for himself.

The traits of negotiation in the I9th-century Finnish pardoning system thus show that delinquents and vagabonds were not merely passive objects of the official control system, but knew how to exploit it as well. The concept of Justiznutzung has been used to describe this kind of interaction between people and the courts in the early modern period. ${ }^{42}$ Perhaps the clearest example of Justiznutzung in the 19th-century Finnish pardoning system was the fact that the initiative to deport vagrants and other delinquents as settlers came from a group of vagrants and delinquents themselves, who petitioned their workhouse and prison sentences to be commuted to a deportation in the Siberian colonies. ${ }^{43}$

In addition to those elements already mentioned, there is yet another aspect in the I9th-century Finnish pardoning system that could be characterized as typical of early modern criminal law, namely, the parlance of the petitions. The majority of all the petitions followed a certain formula. The petitions began with an excessive praise of the Emperor, who was usually addressed as »The Almighty and Most Merciful Emperor «. Next, the actual arguments for the petition were presented. Finally, the petitions ended almost without an exception with the phrase »Your Imperial Majesty's Most Subservient and Loyal Subject«. The reason for the uniformity of the petitions can be explained by the fact that many of the petitions were often written by one and the same person. It was common that in each penal establishment there were a select few convicts who wrote petitions not only for themselves but for the others as well. The skill of drawing up petitions was then probably passed on to the next »confident « when the previous one was released from the establishment.

The formal language of the petitions attests to a claim that petitioning was an important part of the symbolic interaction that

4I P. KIng, Crime, Justice, and Discretion in England $1740-1820$, Oxford 2000, 297-333; C. A. Hoffmann, Die gesellschaftliche und rechtliche Bedeutung von Suppliken im städtischen Strafverfahren des I6. Jahrhunderts. Das Beispiel Augsburg, in: C. Nubola, A. WÜrgler (eds.), Forme (nt. I) 92-93; HärTER, Policey (nt. 5) 507-5II.
42 See Dinges, Justiznutzungen (nt. 5).

43 Juntunen, Suomalaisten (nt. 24) $42-44$. 
took place between the petitioner and the authorities. Petitioning in the early modern period was a kind of ritual through which the subject/petitioner acknowledged the authority and the supremacy of the ruler. In return for his submission, the subject waited expectantly for a favorable decision. It was also important for the ruler to appear merciful in the eyes of his subjects. This type of symbolic interaction did not necessarily actually solve the conflict between the subject and the ruler, but it offered a meaningful channel for communication and helped to maintain the status quo. ${ }^{44}$

4 . ... and Traits of Modern Legalism

Although many features of the early modern pardoning system - i.e. using pardoning to take into account the mitigating circumstances, paying attention to the social capital of the petitioners, and the symbolic character of the procedure - were apparent in the I 9 th-century pardon practice in Finland, traits also arose that point to modern criminal law rather than to early modern criminal law. In comparison to the early modern period, for example, the room for negotiation through petitioning had narrowed considerably. First of all, unlike in early modern continental Europe the "social capital « of the I 9 th-century Finnish criminal or vagrant petitioners was no longer established through »back-up « letters and petitions done by the family or the members of the local community. As mentioned above, it was common in the early modern period that also members of the family and/or local community petitioned on behalf of the accused/condemned. However, the Finnish authorities disregarded all the petitions that were made by those other than the condemned himself. The reason for this was the Decree of I 826, according to which it was forbidden for those other than the culprit himself to send petitions in criminal and vagabond matters. ${ }^{45}$ This argument was used several times as grounds for the dismissal of the petition made, for instance, by the wife of the convicted. ${ }^{46}$ The family and the local community had thus been deprived of their possibility to take part in the negotiations for the final punishment or sanction. This can be considered a modern feature. ${ }^{47}$

The evaluation of a petitioner's character in the I9th-century Finnish pardoning system was therefore solely based on the official documents - i.e. criminal/vagabond records and statements of

44 Rudolph, "Sich der höchsten « (nt. 5) 445-449.

45 Keisarillisen (nt. 2I) $4 \mathbb{\$}$.

46 KotKas, "Suosiosta « (nt. 8) I6I, I66, I 68.

47 Simon Teuscher has shown that the use of different sorts of "private letters « was an important feature of the political culture in the cities of the late Middle Ages. These types of letters were mainly used in order to bring to the at- tention of the authorities the actual requests or claims that were presented in the "official « petitions and applications. Private letters were a common phenomenon in all kind kinds of matters, including legal ones. With reference to Talcott Parsons, Teuscher claims that " $[\mathrm{m}]$ odern politics can be seen as divided between the >universalistic logic of legally regulated administrative institution and the sparticularistic logic of their actual use through personal relationships, kin, and clientelism. Such a distinction would not have been conceivable to people in late medieval Bern. «Simon Teuscher, Chains of Favor. Approaching the City Council in Late Medieval Bern, in: C. Nubola, A. WürgLER (eds.), Forme (nt. I) 326-327. 
the prison/workhouse officials. It is interesting that similar kind of observations have been presented on the significance of the official documents in the pardoning process in 19th-century Bavaria. According to Petra Overath's study, the proposals that the Bavarian Ministers of Justice made to the ruler seem to have been based primarily on the official documents, i.e. the court records and the statement of the public prosecutor. The contents of the petition (those provided by both the delinquent and the family and friends) only seldom had any real influence on the final pardoning decision. ${ }^{48}$

Furthermore, my study revealed that the pardoning power in I9th-century Finland was to a large extent de facto exercised by the Judicial Department of the Senate. Even though the written grounds for the Emperors' decisions were mainly brief - »no grounds for the approval« or »the petition is approved by grace and mercy " - the decisive arguments were reasonably easy to conclude from the opinions of the Judicial Department of the Senate. The Russian Emperors consented to the Justice Department's opinion practically in all the decisions. This was not unusual in the early modern period either, ${ }^{49}$ but the difference now was that the exercise of pardon was, to a great extent, statutorily delegated to the Judicial Department of the Senate. The Judicial Department had, for example, an exclusive authority over the vagabond petitions. Sometimes the competence was even delegated with clear guidelines - i.e. with explicit rules for the decision making. This was the case, for instance, in regard to petitioners who wanted to have their original sentences commuted to a deportation to the Siberian colonies and the petitioners who petitioned their corporal punishment to be commuted to imprisonment on bread and water for medical reasons. The increased authority of the Judicial Department in pardoning matters, as well as the statutory regulation of the grounds of pardoning, both bear witness to emerging legalistic tendencies in I9th-century Finnish criminal law. ${ }^{\circ}$

There is still one important difference between the pardoning system of I9th-century Finland and that of early modern continental Europe - namely, the question of money. In Germany, for instance, significant fiscal interests were involved in the pardoning system. First of all, petitioning itself required administrative payments. In order to institute a petition, the petitioner needed to pay a certain amount of money. The procedure was regulated quite

48 Overath, Tod (nt. 7) I77-I 82. 49 Härter, Policey (nt. 5) 499.

50 Petra Overath has also reported on the ruler's diminishing role in the decision-making process in I9th-century Bavaria. Overath states that after the middle of the century the ruler's influence in the decision-making process weakened significantly. After the Revolution of 1848 the ruler followed mostly the proposals of the Mi- nisters of Justice. Overath emphasizes the significance of criminal politics in the deliberation of the Ministers of the Justice. For instance, throughout the century, all those who were sentenced to death for infanticide were pardoned because the death penalty was considered too harsh. Overath, Tod (nt. 7) I 58-I77. 
strictly by Policeynormen. ${ }^{5 \mathrm{I}}$ Secondly, the death penalty or pillory was often commuted to a pecuniary penalty which could be quite substantial. This was a way to increase the ruler's finances. ${ }^{52}$ By contrast, in I9th-century Finland the petition procedure was mainly regulated in the constitutional legislation - and only quite narrowly. The petitioning did not involve any administrative payments. Furthermore, in all the cases where the original punishment was commuted to some other form of punishment, it was never commuted to a pecuniary penalty. No direct fiscal interests were involved in the rigth-century Finnish pardoning practice. The pardoning system had lost its early modern function as a fiscal instrument.

\section{Pardoning as a Means of Modernizing \\ Finnish Criminal Law}

I hope to have shown by now that the pardoning practice in I9th-century Finland embodied both features of early modern and modern criminal law. On the one hand, the system of pardoning was still used as a means of negotiating the punishment between the condemned and the authorities. For instance, those who had been convicted of manslaughter could still have had their death sentence commuted to life imprisonment, if the Judicial Department of the Senate/Emperor agreed that there were mitigating circumstances in the crime. Vagrant petitioners were released from the workhouse if they proved to have "social capital « and were not considered too great a risk for the society. Original sentences of both criminals and vagrants were also commuted to deportations to Siberia in the name of public security. On the other hand, modern features also appeared. It was forbidden for the family, relatives or the local community to petition for pardon on behalf of the condemned. The decision was primarily based on official documents. Petitioning was thus exclusively a matter between the individual and the authorities. Furthermore, the criteria for pardons were in some cases »legalized «. For example, the prerequisites for commuting delinquents' prison sentences to deportations were statutorily regulated.

The reforms that were carried out in the Finnish criminal law during the 19 th century had a clear impact on the pardoning

5I Concerning Germany, see Här-

TER, Das Aushandeln (nt. 4) 248253; HärTER, Policey (nt. 5) 497500 . On the French pardoning procedure, see e.g. Davis, The Fiction (nt. 33) 7-25.

52 Härter, Das Aushandeln (nt. 4) 26I-262; HärTer, Policey (nt. 5) 515 . 
practice. When capital and corporal punishments were abolished and penal scales introduced in I 866 and I 889 , there was no longer the need to use the pardoning system as a means for negotiating for the punishment or mitigating the harshness of the old Criminal Code of I734. The decision on the final punishment was now the task of the judges. In this respect the development in Finland seems to correspond to the earlier German experience. In German states the petitioning system went through a change during the last third of the 18 th century and the first third of I 9 th century. The change was caused by the reforms in the material as well as in procedural criminal law. For instance, the grounds for mitigation and decision received a standing expression in the criminal law. The criminal procedure in the courts became oral and more direct. Also the possibility to defend oneself and to appeal became a definitive part of the procedure. The petitioning for pardon evolved from an »extra-judicial legal recourse into a fundamental right «. ${ }^{53}$

However, it would be misleading to conclude that the functions that the pardoning system had in the early modern period unilaterally declined and simply gave away to the standards of modern criminal law. On the contrary, the pardoning system did not just turn into a useless relic of earlier centuries, but rather functioned as a kind of transitional tool for modernizing the material criminal law in I9th-century Finland. As already mentioned, the death penalty was abolished in 1826 by a decree in which the Emperor promised pardon for all future death sentences and to commute them to fixed-term or life-long hard labour. Corporal punishments and pillory were also abolished through a consistent pardoning practice during the 1860 s and 1870 s - in other words, decades before the respective reforms in legislation. ${ }^{54}$

It can also be argued that the antecedent pardoning practice paved the way for the introduction of the new parole system in Finland in 1894 . That is to say, the statutorily regulated practice of commuting prison sentences to deportations to Siberia functioned as a model for the parole system. In order to be sent as a settler to the Siberian colonies, the petitioner had to have served a given period of time of his original sentence. It was also required that the prisoner was of proper age, health and character. Similar kinds of prerequisites were adopted in the new statutes concerning parole. The conditions for parole were that the convict's conduct had been blameless, his livelihood outside the prison was secured, and that

53 Härter, Aushandeln (nt. 4) 272273.

54 Pardoning was not the only extralegislative means of reforming criminal law in Igth-century Finland. In addition to the Emperor's right of pardon, the Finnish Courts of Appeal consistently mitigated the unnecessary severity of certain punishments. Between the years I 809-I 894, a total of 630 sentences were mitigated. Appro- ximately $75 \%$ of these concerned delinquents who had been sentenced to the death penalty for robbery. See H. Pihlajamäki, On the Verge of Modern Law? Mitigation of Sentence in Nineteenth-Century Finland, in: Ius Commune 28 (2001) 269-294. 
he had served three-fourths of his sentence. Furthermore, the pardoning system did not only serve as a model for the parole system but assumed a technical function as a part of it. Although the Judicial Department of the Senate was invested with the power of decision in parole matters, the petition still had to be addressed to the Emperor. This link between the pardoning system and the parole system was maintained until 193 I. From then on, the proposal had to be sent to the Ministry of Justice which was also invested with the exclusive authority to release prisoners on parole. ${ }^{55}$

The characterization of the pardoning system as transitional tool within I9th-century Finnish criminal law largely corresponds to what has been presented on the General Prosecutors and their use of the doctrine of aggravating and mitigating circumstances in the Republic of Geneva between 1738 and $1792 .{ }^{56}$ According to Michel Porret's study, the written indictments of the General Prosecutors show that approximately from the 1750 os onwards the General Prosecutors seem to have begun to enforce the principles of legality in their action in order to reduce the arbitrary nature of the administration of criminal justice. To a great extent, this was achieved by applying the early modern doctrine of aggravating and mitigating circumstances. The doctrine stated that each punishment should be carefully made to match the particular conditions of the crime. From the point of view of modern criminal law this doctrine appeared untenable in its particularity. However, also embedded in the doctrine was an inherent idea of the impartiality and equality of criminal law. It was the crime itself, and not the judge, who defined the proper punishment. Even though the doctrine of the circumstances of the crime could not survive modern criminal law and its claims for universality and codification, it was nevertheless an important means for limiting the arbitrariness in the administration of criminal justice. In fact, the theory of the circumstances of the crime functioned as a kind of a "substitute " until the principle of legality was introduced in the Penal Code of $1795 .{ }^{57}$

In conclusion, the co-existence of features of both the early modern and modern pardoning practice, as well as the function of the pardoning system as a transitional tool towards modern criminal law, aptly illustrate that there did not exist a clear rupture between the early modern and modern criminal law in I9th-cen-

55 The I93 I reform did not concern prisoners who were sentenced for life. They still had to petition for pardon in order to be released on parole.

56 M. Porret, Le crime et ses circonstances. De l'esprit de l'arbitraire au siècle des Lumières selon les réquisitoires des procureurs généraux de Genève, Genève I995.

57 Ibid., 4I7-445. 
tury Finland. On the contrary, the pardoning system played a crucial role in the modernizing process of Finnish criminal law - a process that advanced gradually. The pardoning system even adjusted itself to meet the demands of modern criminal law. Perhaps all this gives us a well-reasoned cause to question the persistent divisions that have been said to continue to exist in the research literature on the history of European criminal law. ${ }^{8}$ The Finnish experience of I9th-century pardoning at least shows that the »I8th-century criminal law « extended itself well into the I9th century and that the modernization was gradual rather than abrupt.

Toomas Kotkas

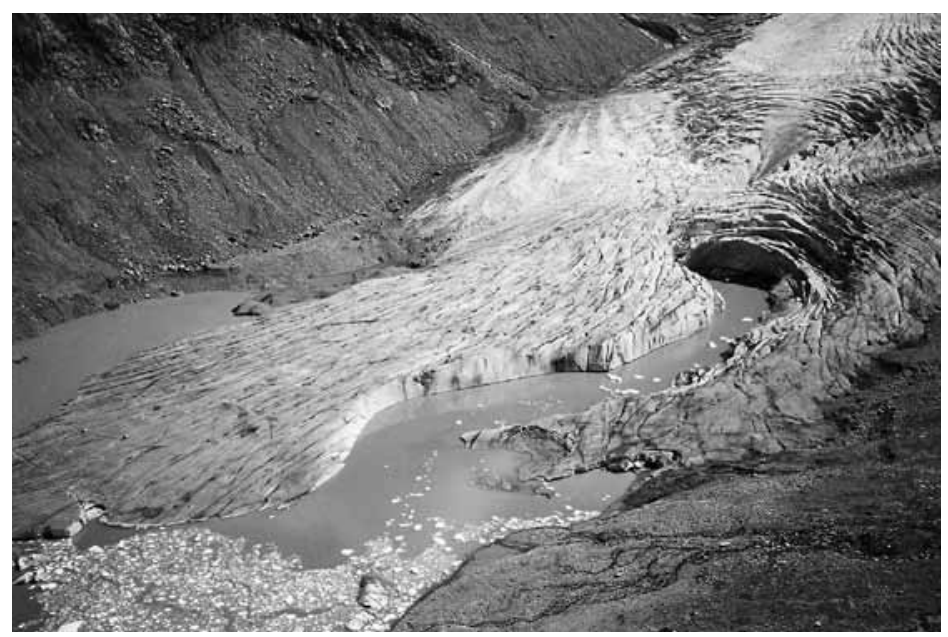

58 Habermas, Von Anselm (nt. 7) I 5 I-I 53. 